\title{
Utilization of personal protective equipment and associated factors among building construction workers in Addis Ababa, Ethiopia, 2019
}

Addisu Alehegn Alemu ${ }^{1 *} \mathbb{D}$, Meseret Yitayew ${ }^{2}$, Aklilu Azazeh ${ }^{3}$ and Sofia Kebede ${ }^{3}$

\begin{abstract}
Background: Personal protective equipment (PPE) is a material, device, equipment, or clothing used or worn by workers to reduce their chance of exposure or contact with any harmful material or energy that causes injury, disease, or even death. The use of PPE is a universal legal requirement to reduce occupational injuries and illnesses in the workplace. Therefore, this study was conducted to assess PPE utilization and its associated factors among building construction workers in Addis Ababa, Ethiopia, 2019.
\end{abstract}

Methods: Institution based quantitative cross-sectional study was conducted on the selected construction sites of Addis Ababa city from April 1 to May 18, 2019. Data were collected among all (206) building construction workers via interviewer-administered questionnaires. Data were entered into Epi info version 7.1 and exported to SPSS version 25 statistical software for analysis. Variables with a $p$-value of less than 0.20 in bivariate analysis were included in multivariate logistic regression. Finally, variables with a p-value of less than 0.05 in multivariate analysis were considered as significantly associated.

Results: The utilization of at least one PPE among building construction workers in Addis Ababa was found to be $38 \%$. The majority (41.1\%) of the participants' reason for not using PPE were the unavailability of PPE followed by absence of orientation on using PPE (21.3\%). The majority (35.3\%) and (32.2\%) of participants knew abrasion as a type of injury and suffered from abrasion respectively. Factors associated with utilization of PPE were the presence of training on PPE use (AOR $=4.8 ; 95 \% \mathrm{Cl}: 2.3,10.3)$, presence of safety training ( $\mathrm{AOR}=2,8 ; 95 \% \mathrm{Cl}: 1.5,5.2)$, safety orientation before commencing work ( $\mathrm{AOR}=4.0 ; 95 \% \mathrm{Cl}: 1.9,9.0)$ and presence of supervision (AOR = 5.0; 95\% Cl:1.9, 13).

Conclusions: PPE utilization among building construction workers in Addis Ababa was low. The main reasons for non-utilization of PPE were unavailability of the materials and the absence of orientation on using PPE. The presence of PPE use training, presence of safety training, safety orientation, and governmental supervision were factors associated with PPE utilization. There should be continuous supervision of construction sites to assure all workers get material and training on how to use it.

Keywords: Personal protective equipment, Construction workers, Ethiopia

\footnotetext{
*Correspondence: addisua4@gmail.com; addisu_alehegn@dmu.edu.et

${ }^{1}$ College of Health Sciences, Debre Markos University, Debre Markos, Ethiopia

Full list of author information is available at the end of the article
}

(c) The Author(s). 2020 Open Access This article is licensed under a Creative Commons Attribution 4.0 International License, which permits use, sharing, adaptation, distribution and reproduction in any medium or format, as long as you give appropriate credit to the original author(s) and the source, provide a link to the Creative Commons licence, and indicate if changes were made. The images or other third party material in this article are included in the article's Creative Commons licence, unless indicated otherwise in a credit line to the material. If material is not included in the article's Creative Commons licence and your intended use is not permitted by statutory regulation or exceeds the permitted use, you will need to obtain permission directly from the copyright holder. To view a copy of this licence, visit http://creativecommons.org/licenses/by/4.0/ The Creative Commons Public Domain Dedication waiver (http://creativecommons.org/publicdomain/zero/1.0/) applies to the data made available in this article, unless otherwise stated in a credit line to the data. 


\section{Background}

Personal protective equipment (PPE) is any equipment used to eliminate or minimize a specific occupational injury by a worker [1-3]. Its utilization is a universal, legal requirement and recommended action of workers to protect themselves from injuries in their workplace [3, 4]. Though the occupational injury is a global public health problem, it is the worst in the developing countries but can be prevented through effective use of the necessary PPE during work $[3,5,6]$.

According to the International Labor Organization (ILO) and World Health Organization (WHO) 270 million occupational accidents [6],160 million new cases of occupational diseases respectively are caused annually by exposure and dangerous conditions at the workplace; $30-40 \%$ of these can end up with chronic diseases, permanent disability, pulmonary impairment and premature death [5, 7-11]. Building construction is a complex sector where injuries at the workplace are enormous [3] and are hurtful to the employee, the employer, and society [5]. The probability of a fatal accident in the construction industry is five times the probability of an accident in the manufacturing industry [12].

The impact of occupational health and safety hazards faced by construction workers in developing countries is 10 to 20 times higher than those in industrialized countries [13]. Workers in the construction sectors are more exposed to physical, psychological, biological, and chemical risk factors [14]. Safety issues in the construction industry receive inadequate attention and provision in the developing world. This is due to owing to cost, lack of enforcement, and ignorance of the stakeholders [15]. Occupational injuries pose major public health and developmental problems; which result in serious health, social, and economic consequences on workers and their employers [5]. Employees must understand when is necessary to use, what equipment is required, how to use or wear, how to care, how to know when the equipment has reached the end of its useful life and how to dispose of PPE $[6,16,17]$. The prevalence of occupational injury is high which is by low PPE usage [18].

There are huge and numerous building construction projects with many occupational injuries (including death) in Addis Ababa, Ethiopia, however PPE utilization and its determinants among building construction workers are not well known. Therefore, this study identified the use of PPE and its determinants among building construction workers in Addis Ababa, Ethiopia.

\section{Methods}

Study area, design, period and population

A facility-based quantitative cross-sectional study was conducted at selected construction sites of Addis Ababa City that have direct regulatory communication with Addis Ababa city administration construction office. The study was conducted to assess PPE utilization and its determinants among building construction workers from April 1 to May 18, 2019. Addis Ababa is the capital and largest city of Ethiopia and a head seat for the African Union, home for more than 92 embassies and consular representatives and international agencies. Among numerous construction companies in Addis Ababa, only five of them were regulated by the government [5]. This study included all construction sites that had direct regulation with Addis Ababa construction office during the study period. All construction site workers in these sites were included.

\section{Sample size determination and sampling procedure}

All construction site workers (206) in the five sites who were functional and regulated directly by Addis Ababa construction office during the study period were included in this study (Fig. 1).

\section{Data collection technique and study variables}

Data were collected using translated structured Amharic questionnaires developed after intensive review of previous studies related to this study. Data were collected using face-to-face interviews. Questionnaires included socio-demographic, behavioral, and environmental factors that can affect PPE utilization. Data were collected by six BSc health professionals under the supervision of two MSc candidates.

\section{Data quality, processing, and analysis}

Proper designing and pretesting of the questionnaire in 5\% (11 construction workers) of the participants was conducted in one building construction site other than the selected sub-city (Akaki). Two days of training before and after the pretest was given to data collectors and supervisors. They were trained about the objectives of the study, the questionnaire's content, the data collection techniques, and the way how confidentiality maintained throughout the study. In addition, there was were daily checking of the incompleteness and inconsistencies of questionnaires. The collected data were entered into Epi Info version 7.1 (Atlanta, GA) and exported to SPSS version 25 (Armonk, NY: IBM Corp) for statistical analysis. During analysis, those variables in bivariate analysis with a $p$-value of less than 0.20 were included in multivariate logistic regression. Finally, multivariate analysis was computed and variables with p-value less than 0.05 were considered as significantly associated.

\section{Definition of terms}

Personal protective equipment

Any material, device, equipment or clothing which is used or worn by a worker to protect them from 


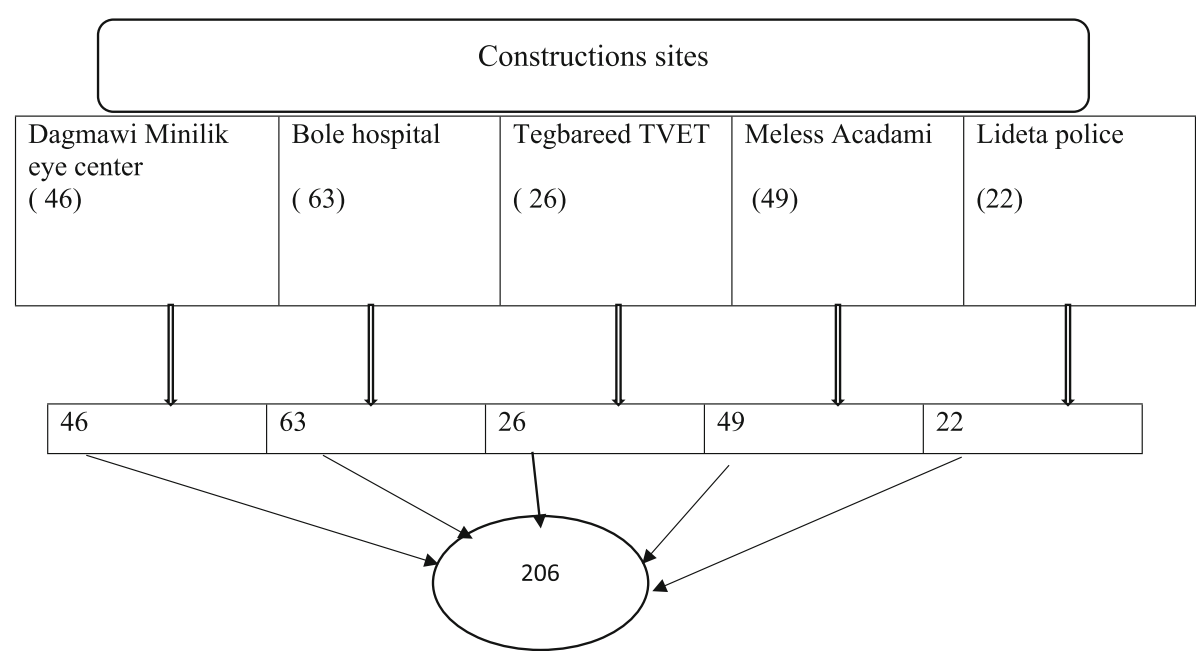

Fig. 1 A selection of study participants for PPE utilization among building construction site workers in Addis Ababa, Ethiopia, 2019

exposure or contact with any harmful material or energy which may cause injury, disease or even death to the worker, such as earplugs, Googles, Overalls, gloves, helmets and safety shoes [19].

\section{PPE utilization}

The use of at least one PPE consistently and appropriately to prevent injuries and illness.

\section{Results}

Socio-demographic characteristics

A total of 206 respondents were interviewed with a response rate of $100 \%$. This study showed that $62 \%$ of participants had not used even a single personal protective equipment (Fig. 2). Three in 10 of the respondents were female. The mean age of respondents was 25.5 $(\mathrm{SD} \pm 4.07)$ years. The majority $(88.3 \%)$ of respondents were below 30 years old. The study also showed six in 10

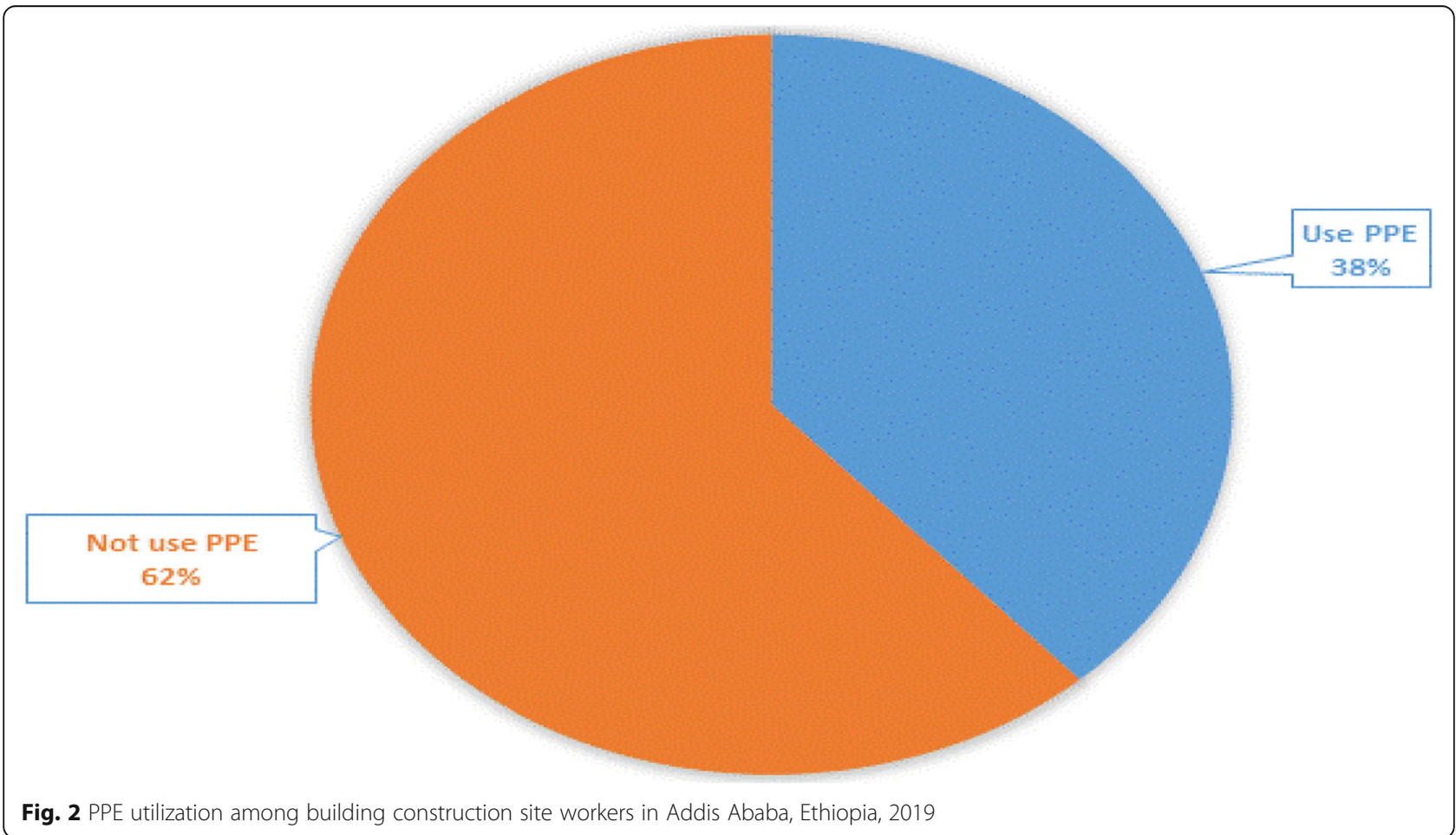


were single. Three in 10 had no formal education, whereas, 26.2 and $23.8 \%$ of the participants had primary and secondary educational status, respectively. The majority (71.4\%) of workers were recruited on a daily basis (Table 1).

\section{Reasons for not utilizing PPE}

This research identified the reasons for not using PPEs. The majority of participants $(41.1 \%)$ reported they did not use PPE due to the unavailability of PPE, followed by $(21.3 \%)$ due to lack of orientation on PPE usage. Similarly, 16.3, 11.3, and $10 \%$ of participants reasons for not using were the PPEs were not comfortable, PPEs are not important and have no reason at all, respectively.

\section{Type of injuries known and suffered by the participants}

This study identified that the most commonly perceived type of injury was abrasion (35.3\%) and only $2 \%$ of the participants perceived permanent disability at the building construction site. Almost one-third of participants suffered abrasion whereas one or two out of 10 participants suffered from a bone fracture. Multiple causes of injury and more than one perception were identified (Table 2).

Table 1 Socio-demographic characteristics of building construction workers in Addis Ababa, Ethiopia, 2019

\begin{tabular}{llll}
\hline Variable & Category & Frequency & Percent \\
\hline Sex & Male & 157 & 76.2 \\
Age & Female & 49 & 23.8 \\
& $<=30$ & 182 & 88.3 \\
Marital status & $>30$ & 24 & 11.7 \\
& Married & 81 & 39.3 \\
Working hour & Dingle & 122 & 59.2 \\
& Divorced & 3 & 1.5 \\
& 5-6han $5 \mathrm{~h}$ & 7 & 3.4 \\
& $7-8 \mathrm{~h}$ & 7 & 3.4 \\
& $9-10 \mathrm{~h}$ & 162 & 78.6 \\
& $11-12 \mathrm{~h}$ & 19 & 9.2 \\
Working experience & $\leq 1$ year & 11 & 5.3 \\
& $>1$ \& $<5$ years & 123 & 59.7 \\
& $\geq 5 \&<10$ years & 15 & 30.6 \\
& $\geq 10$ years & 5 & 2.3 \\
Term of employment & Fixed contract & 59 & 28.6 \\
& Daily & 147 & 71.4 \\
& No formal education & 62 & 30.1 \\
& Primary & 54 & 26.2 \\
& Secondary & 49 & 23.8 \\
& College / Above & 41 & 19.9 \\
\hline
\end{tabular}

Table 2 Type of injuries known and suffered among building construction site workers in Addis Ababa, Ethiopia, 2019

\begin{tabular}{llll}
\hline Variables & & Frequency & Percent \\
\hline Type of injury known & Abrasion & 140 & 35.3 \\
& Piercing/Cut & 93 & 22.7 \\
& Muscular pain & 71 & 18 \\
& Bone fracture & 46 & 11.5 \\
& Sprain/strain & 39 & 10.5 \\
& Permanent disability & 10 & 2 \\
Type of injury suffered & Abrasion & 109 & 32.2 \\
& Piercing/Cut & 104 & 30.8 \\
& Bone fracture & 46 & 13.6 \\
& Sprain/Strain & 34 & 10.1 \\
& Muscular pain & 26 & 7.7 \\
& Back pain & 19 & 5.6 \\
\hline
\end{tabular}

\section{Preparedness for injury prevention}

In this study preparedness of injury prevention was assessed, the majority (84.5\%) of participants knew at least one type of PPE, only nearly one third (31.6\%) the participants took safety training and around four out of 10 participants had been oriented about PPE before commencing their work (Table 3 ).

\section{Factors associated with PPE utilization}

Independent variables like age, level of education, the term of employment, year of experience, availability of safety training, PPE utilization training, perception of injury, knowledge on PPE, safety brief before commencing work and availability of enforcement or pressure to use PPE was tested by binary logistic regression. Variables with a $p$-value of less than 0.2 during the bivariate analysis were included in the multivariate logistic regression. Based on this, safety training, PPE use training, safety brief before commencing work, and governmental visit showed association with PPE utilization. Those who took general safety training on PPE use were about 3 times more likely to use personal protective equipment $(\mathrm{AOR}=2.8 ; 95 \% \mathrm{CI}: 1.5,5.2)$ than those who had not. Those who had been briefed about safety before commencing work were 4 times more likely to use personal

Table 3 Preparedness for injury protection among building construction workers in Addis Ababa, Ethiopia, 2019

\begin{tabular}{llll}
\hline Variable & & Frequency & Percent \\
\hline Knows any PPE & Yes & 174 & 84.5 \\
& No & 32 & 15.5 \\
Took safety training & Yes & 65 & 31.6 \\
& No & 141 & 68.4 \\
Orientated about PPE & Yes & 73 & 35.4 \\
& No & 133 & 64.6 \\
\hline
\end{tabular}


protective equipment (AOR $=4.0 ; 95 \%$ CI:1.9, 9.0). Those who had PPE use training are 4.8 times more likely to use PPE (AOR $=4.8 ; 95 \% \mathrm{CI}: 2.3,10.3)$ and workers in the sites where there was supervision by the governmental concerned body were 5 times more likely to use PPE AOR $=5.0 ; 95 \% \mathrm{CI}: 1.9,13)$ than who did not (Table 4).

\section{Discussion}

Occupational injuries which are the global public challenges [20] are common among building construction workers [21]. All workers in the construction industry should be trained on the proper use of PPE [22] to get them protected from potential occupational hazards [23]. Determining factors associated with PPE utilization among workers is vital for implementing the safety work promotion programs [3]. The purpose of this study was to determine the utilization of PPE and its associated factors among building construction workers in Addis Ababa, Ethiopia. The study included only construction sites directly regulated by the Addis Ababa construction office were included to identify the PPE utilizations though they were regulated.

In this study, the PPE utilization among construction site workers was $38 \%$. The utilization of PPE in this study is in line with a study conducted in Cairo, Egypt (31.4\% [24], but lower than studies conducted in Hawassa, Ethiopia (82.4\%) [25] and Kampala, Uganda (50.4\%) [26]. This might be due to differences in methodological differences, study populations, and study areas. The two main reasons for not using PPE identified in this study were unavailability of PPE (41.1\%) and lack of orientation on how to use PPE (21.3\%). Similar studies also identified the reasons for not using PPE was the

Table 4 Factors associated with personal protective equipment utilization among building construction workers in Addis Ababa, Ethiopia, 2019

\begin{tabular}{|c|c|c|c|c|c|}
\hline \multirow[b]{2}{*}{ Variable } & & \multicolumn{3}{|c|}{ PPE use } & \multirow[b]{2}{*}{ AOR $(95 \% \mathrm{Cl})$} \\
\hline & & Yes & No & COR $(95 \% \mathrm{Cl})$ & \\
\hline \multirow[t]{2}{*}{ Age } & $\leq 30$ & 73 & 109 & $2.01(0.76,5.30)$ & $0.90(0.24,3.39)$ \\
\hline & $>30$ & 6 & 18 & 1 & 1 \\
\hline \multirow[t]{4}{*}{ Level of education } & Illiterate & 18 & 44 & $1.73(0.75,3.96)$ & $2.37(0.8,7.02)$ \\
\hline & Primary & 20 & 34 & $1.20(0.52,2.76)$ & $1.65(0.56,4.87)$ \\
\hline & Secondary & 24 & 25 & $0.74(0.32,1.70)$ & $1.01(0.34,2.97)$ \\
\hline & > College & 17 & 24 & 1 & 1 \\
\hline \multirow[t]{2}{*}{ Term of employment } & Fixed contract & 18 & 41 & $0.62(0.33,1.18)$ & $0.72(0.30,1.68)$ \\
\hline & Daily & 61 & 86 & 1 & 1 \\
\hline \multirow[t]{4}{*}{ Year of experience } & $<1$ & 45 & 78 & 1 & 1 \\
\hline & $1-5$ & 24 & 39 & $0.40(0.04,3.85)$ & $0.55(0.42,7.02)$ \\
\hline & $6-10$ & 9 & 6 & $0.17(0.01,1.88)$ & $0.25(0.02,3.93)$ \\
\hline & $>10$ & 1 & 4 & $0.43(0.05,4.00)$ & $0.47(0.38,5.64)$ \\
\hline \multirow[t]{2}{*}{ Safety training } & Yes & 36 & 29 & $2.83(1.54,5.19)^{* * *}$ & $2.30(1.08,5.06)^{*}$ \\
\hline & No & 43 & 98 & 1 & 1 \\
\hline \multirow[t]{2}{*}{ PPE use training } & yes & 48 & 27 & $5.73(3.08,10.66)^{* * *}$ & $4.80(2.26,10.27)^{* * *}$ \\
\hline & No & 31 & 100 & 1 & 1 \\
\hline \multirow[t]{2}{*}{ Perceives Any Injury } & Yes & 75 & 111 & 1 & 1 \\
\hline & No & 4 & 16 & $0.37(0.12,1.15)$ & $0.87(0.20,3.64)$ \\
\hline \multirow[t]{2}{*}{ Suffer Injury } & Yes & 70 & 100 & 1 & 1 \\
\hline & No & 9 & 27 & $0.47(0.21,1.07)$ & $0.77(0.26,2.26)$ \\
\hline \multirow[t]{2}{*}{ Knows any PPE } & Yes & 74 & 100 & 1 & 1 \\
\hline & No & 5 & 27 & $0.25(0.92,0.68)^{* *}$ & $0.48(0.13,1.67)$ \\
\hline \multirow[t]{2}{*}{ Orientated about PPE } & Yes & 44 & 29 & $4.25(2.31,7.79)^{* * *}$ & $4.00(1.92,8.98)^{* * *}$ \\
\hline & No & 35 & 98 & 1 & 1 \\
\hline \multirow[t]{2}{*}{ Presence of supervision } & Yes & 27 & 9 & $6.80(2.99,15.49)^{* * *}$ & $5.00(1.93,13.10)^{* * *}$ \\
\hline & No & 52 & 118 & 1 & 1 \\
\hline
\end{tabular}

Significant codes: $* * * 0.001 * *<0.01 *<0.05$ 
unavailability of PPE [23] uncomfortable, not designed for hot and cold weather, and heaviness [22, 27, 28]. Other reasons might be due to lack of interest and awareness from workers, lack of concern from responsible bodies, and uncomfortable PPE.

This study revealed safety training as a significant factor of PPE utilization. Workers who have not taken safety training were less likely to utilize PPE. This was supported by previous studies $[8,29-36]$. Similarly, those who had not been trained on PPE utilization were less likely to utilize PPE in line with the previous studies [32, 36]. On the other hand, inadequate or lack of training on PPE usage shows low PPE utilization [37]. This might be due to the reason training workers on safety and proper PPE use promotes [34, 38]. It has paramount advantages on appropriate utilization of PPE [39] which is intended to prevent the risk of worksite injuries [40, 41].

This study, similar to previous studies [30, 31, 42-44], identified supervision on PPE usage was significantly associated with PPE utilization. Those who had been supervised on their PPE usage were 5 times more likely to utilize PPE compared to those who had not been supervised. The reason behind this could be that workers who are supervised and reminded of the applications of PPE [24] might be enforced to use PPE with fear of not being subjected for criticism or even days or total off [43]. Additionally, this study showed safety orientation before commencing work was a significant factor affected PPE utilization. Those who had been oriented before commencing work were 4 times more to use PPE than those who had not been oriented. This finding is supported by previous studies $[45,46]$.

\section{Limitation of the study}

Since the list was taken from the employers, workers who might be absent from work due to injury might not be included in this study.

\section{Conclusions}

This study showed only $38 \%$ of workers utilized PPE. The majority of respondents' reason for not using PPE was the unavailability of PPE. Abrasion and piercing /cut were a common type of injury and clamping at high and dust/fug are common reasons. There should be training on PPE use before commencing work to strengthen workers' safety and improve the productivity of manufacturing industries.

\section{Abbreviations}

AAU: Addis Ababa Universit; ILO: International Labour Organization; OSHA: US Occupational Safety and Health Administration; PPE: Personal Protective Equipment; UN: United Nation; WHO: World Health Organization; COR: Crude odds ratio; AOR: Adjusted Odds Ratio; Cl: Confidence interval

\section{Acknowledgments}

We would like to express our deepest heartfelt thanks to Addis Ababa University for allowing the conduct of this study. Our special thanks go to all participants.

\section{Authors' contributions}

AAA and MY were involved in the conception, design, analysis, interpretation, report and manuscript writing. AKA and SK were involved in the design, analysis, interpretation and report writing. All authors read and approved the final manuscript.

\section{Funding}

There is no funding for this study.

\section{Availability of data and materials}

The data that support the findings of this study are available from the corresponding authors upon reasonable request.

\section{Ethics approval and consent to participate}

Ethical clearance was taken from AAU College of Medicine ethical review committees. A formal permission letter was obtained from the city government of the Addis Ababa Construction office before data collection for each study site. Written informed consent was taken after a clear description of the objectives of the study and its procedures for participants before proceeding data collection.

Consent for publication

Not applicable.

\section{Competing interests}

The authors declare that they have no competing interests.

\section{Author details}

${ }^{1}$ College of Health Sciences, Debre Markos University, Debre Markos, Ethiopia. ${ }^{2}$ College of Health Sciences, Assosa University, Assosa, Ethiopia. ${ }^{3}$ Department of Emergency Medicine, School of Medicine, College of Health Sciences, Addis Ababa University, Addis Ababa, Ethiopia.

Received: 25 February 2020 Accepted: 10 May 2020

Published online: 27 May 2020

\section{References}

1. LaDou J. International occupational health. Int J Hyg Environ Health. 2003; 206(4-5):303-13

2. Goetsch DL. Occupational safety and health. Pearson India; 2010.

3. Kakaei H, Mirzaei Alavijeh M, Mahboubi M, Maghsodi Moghadam R, Zinat Motlagh F, Farasaty F. Factors related to personal protective equipment use between factory cement employ in Ilam, the west of Iran: application of BASNEF model. J Sci Today's World. 2014;3(2):56-9.

4. Shinde M, Sadare S, Potdar N. Awareness of occupational health hazards among staff nurses. Int J Sci Res. 2016:5(12):2319-7064.

5. Tolera TB. Occupational hazards in the construction industry: case studies from housing and construction workers at Addis Ababa. Ethiopia Int J Res Granthaalayah. 2016:4(9):84-96.

6. Tadesse S, Israel D. Occupational injuries among building construction workers in Addis Ababa. Ethiopia J Occup Med Toxicol. 2016;11(1):16.

7. Ayikoru M, Ddamulira C, Mutekanga DR. Determinants of employee use of personal protective equipment, the case of Spedag Interfreight Uganda limited. Kampala. 2019;3(3):419-34.

8. Ayikoru M, Ddamulira C, Mutekanga DR. Determinants of employee use of personal protective equipment, the case of Spedag Interfreight Uganda limited, Kampala. J Env Sci. 2019:3(3):419-34.

9. Gebremeskel TG, Yimer T. Prevalence of occupational injury and associated factors among building construction workers in Dessie town, Northeast Ethiopia; 2018. BMC Res Notes. 2019;12(1):481.

10. Occupational Injuries And Associated Factors Among Building Construction Workers In Bole Sub City, Addis ABABA, ETHIOPIA. BY. 2017;.

11. Johncy SS, Ajay KT, Dhanyakumar G, Raj NP, Samuel TV. Dust exposure and lung function impairment in construction workers. J Physiol Biomed Sci. 2011;24(1):9-13. 
12. Dorji K, Hadikusumo BHW. Safety management practices in the Bhutanese construction industry. J Constr Dev Ctries. 2006;11(2):53-75.

13. Rantanen J. Global strategy on occupational health for all. Afr Newsl Occup Heal Saf. 1996;6:86-9.

14. Mersha H, Mereta ST, Dube L. Prevalence of occupational injuries and associated factors among construction workers in Addis Ababa. Ethiopia J Public Heal Epidemiol. 2017;9(1):1-8.

15. Kibe KN. Assessment of health and safety management on construction sites in Kenya: a case of construction projects in Nairobi County. Nairobi: Jomo Kenyatta University of Agriculture and Technology; 2016.

16. Berhanu F, Gebrehiwot M, Gizaw Z. Workplace injury and associated factors among construction workers in Gondar town. Northwest Ethiopia BMC Musculoskelet Disord. 2019;20(1):523.

17. Kaur D. An organization based cross-sectional study of occupational injuries among bridge construction workers in an urban area of Mumbai. Int J Commun Med Public Heal. 2019;6(3):1211.

18. Izudi J, Ninsiima $V$, Alege JB. Use of personal protective equipment among building construction workers in Kampala, Uganda. J Environ Public Health 2017;2017.

19. Reynaud E. The International Labour Organization and the living wage: a historical perspective. Int Labour Off Geneva. 2017.

20. Lopez-Valcarzel A. Occupational safety and health in the construction work. Afr Newsl Occup Heal Saf. 2001;11(1):4-6.

21. Adane MM, Gelaye KA, Beyera GK, Sharma HR, Yalew WW. Occupational injuries among building construction workers in Gondar City, Ethiopia. Occup Med Heal Aff. 2013;

22. Osonwa Kalu O, Eko Jimmy E, Ozah HP. Utilization of personal protective equipments (PPEs) among wood factory workers in Calabar Municipality, Southern Nigeria. Age. 2015;15(19):14.

23. Acharya SR. Utilization pattern of personal protective equipment among industrial workers of Nawalparasi, Nepal. Heal Prospect. 2014;13(2):24-7.

24. Kamal AAM, Sayed GM, Hassan MH, Massoud AA. Usage of personal protective devices among Egyptian industrial workers. Am J Ind Med. 1988; 13(6):707-16.

25. Tadesse S, Kelaye T, Assefa Y. Utilization of personal protective equipment and associated factors among textile factory workers at Hawassa town. Southern Ethiopia J Occup Med Toxicol. 2016;11(1):6

26. Mulyowa A. Factors associated with use of personal protective equipment among temporary construction workers in Makindye division, Kampala. 2019.

27. Australia SW. Work health and safety perceptions: manufacturing industry. Canberra Safe Work Aust 2015;

28. Loosemore M, Malouf N. Safety training and positive safety attitude formation in the Australian construction industry. Saf Sci. 2019;113:233-43.

29. Lombardi DA, Verma SK, Brennan MJ, Perry MJ. Factors influencing worker use of personal protective eyewear. Accid Anal Prev. 2009;41(4):755-62.

30. Gebrezgiabher BB, Tetemke D, Yetum T. Awareness of occupational hazards and utilization of safety measures among welders in Aksum and Adwa towns, Tigray region, Ethiopia, 2013. J Environ Public Health 2019;2019.

31. Tetemke DAK, Tefera Y, Sharma HR, Worku W. Knowledge and practices regarding safety information among textile workers in Adwa town. Ethiopia Sci Postprint. 2014;1(1):5.

32. Ngwu FA, Alabere ID, Douglas KE. Prevalence of falls and associated factors among construction Workers in Port Harcourt. Nigeria. 2019;14(1):1-16.

33. Beyene Gebrezgiabher B, Tetemke D, Yetum T. Awareness of occupational hazards and utilization of safety measures among welders in Aksum and Adwa towns, Tigray region, Ethiopia, 2013. J Environ Public Health. 2019;2019.

34. Ngwu FA, Alabere ID, Douglas KE. Prevalence of falls and associated factors among construction Workers in Port Harcourt, Nigeria. Asian J Med Heal. 2019:1-16.

35. Motbainor A. Assessment of knowledge and practice on safety information among factory workers. Addis Abeba Universty; 2007.

36. MacFarlane E, Chapman A, Benke G, Meaklim J, Sim M, McNeil J. Training and other predictors of personal protective equipment use in Australian grain farmers using pesticides. Occup Environ Med. 2008;65(2):141-6.

37. Okello TR, Kansime K, Odora J, Apio JA, Pecorella I. Barriers and factors affecting personal protective equipment usage in St. Mary's hospital Lacor in northern Uganda. East Cent African J Surg. 2017;22(1):59-65.

38. Bondori A, Bagheri A, Damalas CA, Allahyari MS. Use of personal protective equipment towards pesticide exposure: farmers' attitudes and determinants of behavior. Sci Total Environ. 2018:639:1156-63.
39. Garcia AM, Boix P, Canosa C. Why do workers behave unsafely at work? Determinants of safe work practices in industrial workers. Occup Environ Med. 2004;61(3):239-46.

40. Cohen A, Colligan MJ, Sinclair R, Newman J, Schuler R. Assessing occupational safety and health training. Cincinnati, $\mathrm{OH}$ Natl Institutes Heal. 1998:1-174.

41. Lindell MK. Motivational and organizational factors affecting implementation of worker safety training. Occup Med. 1994;9(2):211-40.

42. Lette A, Ambelu A, Getahun T, Mekonen S. A survey of work-related injuries among building construction workers in southwestern Ethiopia. Int J Ind Ergon. 2018:68:57-64

43. Ayu BF, Tualeka AR, Wahyudiono YDA. The analysis of factors which are related to the compliance of welder workers in using workplace personal protective equipment in Pt. pal Indonesia. Ind J Public Heal Res Dev. 2018; 9(5):47-52.

44. Ogundipe KE, Owolabi JD, Olanipekun EA, Olaniran HF, Akuete E, Fagbenle AO. Factors affecting effective use of safety wears among construction site operatives: lessons from indigenous firms in South Western Nigeria. Int Appl Eng Res. 2018;13(6):4314-25.

45. Hameed HS, ALY HA, El Latif OA. An intervention study to evaluate compliance with personal protective equipment among workers at textile industry. J Am Sci. 2012:8:117-21.

46. Demeke A. Assessment of the utilization of personal protective equipment among textile industry Workers in Dukem Town. Addis Abeba University; 2017.

\section{Publisher's Note}

Springer Nature remains neutral with regard to jurisdictional claims in published maps and institutional affiliations.
Ready to submit your research? Choose BMC and benefit from:

- fast, convenient online submission

- thorough peer review by experienced researchers in your field

- rapid publication on acceptance

- support for research data, including large and complex data types

- gold Open Access which fosters wider collaboration and increased citations

- maximum visibility for your research: over $100 \mathrm{M}$ website views per year

At $\mathrm{BMC}$, research is always in progress.

Learn more biomedcentral.com/submissions 